\title{
Characterization of the major catalase from Streptomyces coelicolor ATCC 10147
}

\author{
Hyoung-pyo Kim, Jong-Soo Lee, Yung Chil Hah and Jung-Hye Roe
}

Author for correspondence: Jung-Hye Roe. Tel: +82 2880 6706. Fax: +8228884911.

Department of Microbiology, College of Natural Sciences, and Research Center for Molecular Microbiology, Seoul National University, Seoul 151-742, Korea

\begin{abstract}
Streptomyces coelicolor ATCC 10147 produced catalases whose electrophoretic mobility varied depending on the growth phase in liquid culture. Polyacrylamide gel electrophoresis of cell extracts resulted in six catalase activity bands, which were designated Cat1 to Cat6. Of these, Cat4 appeared during all growth phases, whereas Cat1 appeared only during the stationary phase. Catalase-deficient mutants were screened by the $\mathrm{H}_{2} \mathrm{O}_{2}$ bubbling test following NTG mutagenesis. In all the non-bubbling mutants tested, the Cat4 activity band significantly decreased or disappeared, suggesting that Cat 4 is the major catalase. Cat4 was purified to electrophoretic homogeneity and some of its properties analysed. The enzyme has a native molecular mass of $225 \mathrm{kDa}$, as determined by gel permeation column chromatography, and consists of four identical subunits of $57 \mathrm{kDa}$, as determined by SDS-PAGE. The enzyme contains 2.6 molecules of protohaem IX per tetramer, as indicated by the absorption spectrum. It was not reducible by sodium dithionite and exhibited no peroxidase activity with o-dianisidine as the substrate. All these characteristics, as well as inhibitor studies, indicate that the major vegetative catalase in $S$. coelicolor, unlike $E$. coli vegetative catalase, is a member of the typical monofunctional catalases found in eukaryotes and some bacteria.
\end{abstract}

Keywords: Streptomyces coelicolor, catalase

\section{INTRODUCTION}

All aerobic organisms have evolved specific enzyme systems to neutralize potentially lethal reactive oxygen species, including the superoxide anion, hydrogen peroxide and the hydroxyl radical as well as singlet oxygen (Cadenas, 1989; Morgan et al., 1986; Halliwell, 1990). Among these systems two types of enzyme exist to remove hydrogen peroxide within cells: catalases and peroxidases. The former catalyse electron pair transitions in which $\mathrm{H}_{2} \mathrm{O}_{2}$ is decomposed to $\mathrm{O}_{2}$ and $\mathrm{H}_{2} \mathrm{O}$, whereas the latter catalyse single electron transfers resulting in the oxidation of various organic compounds by $\mathrm{H}_{2} \mathrm{O}_{2}$ (Deisseroth \& Dounce, 1970; Dunford \& Stillman, 1976).

Most of the catalases characterized so far can be classified as belonging to one of two types: typical catalases and bifunctional catalase-peroxidases. The typical catalases, which are commonly isolated from animals (Dunford \& Stillman, 1976; Schonbaum \& Chance, 1976), plants (Esaka \& Asahi, 1982) and micro-organisms (Herbert \& Pinsent, 1948; Clayton, 1959), resemble each other very closely; they are composed of four subunits of equal size, containing 2.5-4 haemin prosthetic groups per tetramer with a combined molecular mass in the range
$225-270 \mathrm{kDa}$, show a broad optimum $\mathrm{pH}$ in the range of 5-10, are resistant to treatment with ethanol/chloroform, and are specifically inhibited by 3-amino-1,2,4-triazol (Margoliash et al., 1960). Bifunctional catalaseperoxidases, which until now have been detected only in bacteria (Diaz \& Wayne, 1974; Claiborne \& Fridovich, 1979; Nies \& Schlegel, 1982; Loewen et al., 1985a; Hochman \& Shemesh, 1987; Nadler et al., 1986), share several properties which distinguish them from the typical catalases; their catalytic activity is $\mathrm{pH}$-dependent with a $\mathrm{pH}$ optimum at $6-6.5$, they are more sensitive to temperature, ethanol/chloroform and $\mathrm{H}_{2} \mathrm{O}_{2}$ than the typical catalases and are insensitive to 3-amino-1,2,4triazol (Goldberg \& Hochman, 1989a; Hochman et al., 1992).

While some organisms produce only one type of catalase, more than one catalase has been shown to be present in organisms such as Escherichia coli (Claiborne \& Fridovich, 1979; Claiborne et al., 1979), Saccharomyces cerevisiae (Seah et al., 1973; Seah \& Kaplan, 1973), Bacillus subtilis (Loewen \& Switala, 1987b, c) and Klebsiella pneumoniae (Goldberg \& Hochman, 1989a, b).

In a previous study, Lee et al. (1993) have shown that Streptomyces coelicolor ATCC 10147 became resistant to 
killing by hydrogen peroxide $\left(\mathrm{H}_{2} \mathrm{O}_{2}\right)$ when pretreated with non-lethal concentrations of $\mathrm{H}_{2} \mathrm{O}_{2}$, and that the specific activities of catalase, peroxidase, glutathione reductase and glucose-6-phosphate dehydrogenase increased. The $\mathrm{H}_{2} \mathrm{O}_{2}$-resistant mutants produced 2-8-fold more catalase activity than the wild-type, suggesting that catalase plays an important role in oxidative defence in this organism. In this paper, we describe an investigation of the catalases present in $S$. coelicolor and report on the purification and characterization of the major vegetative catalase.

Media and culture conditions. Growth and maintenance of $S$. coelicolor A TCC 10147 were essentially as described by Hopwood et al. (1985). Pre-germinated spores or seed-culture of $S$. coelicolor were inoculated in minimal medium and grown at $30^{\circ} \mathrm{C}$ with vigorous shaking. The growth phases of the culture were determined by measuring $\mathrm{OD}_{640}$, the weight of dried mycelium, or DNA content (Baserga, 1989; Lee, 1994).

Mutagenesis with NTG and screening for catalase-deficient mutants. Spores were treated with NTG (1 or $\left.3 \mathrm{mg} \mathrm{ml}^{-1}\right)$ to a survival ratio of $0 \cdot 1-1 \cdot 0 \%$ and plated on Bennet's medium (Jones, 1949). Catalase activity was screened by applying a drop of $30 \%(\mathrm{v} / \mathrm{v}) \mathrm{H}_{2} \mathrm{O}_{2}$ with a syringe to the edge of each colony. Catalase-deficient cells failed to evolve oxygen bubbles and were selected and immediately restreaked on fresh Bennet's medium.

Catalase activity assays. Catalase activity was measured spectrophotometrically by following the rate of decrease in absorbance at $240 \mathrm{~nm}$ caused by the disappearance of $\mathrm{H}_{2} \mathrm{O}_{2}$ (Beers \& Sizer, 1952). The absorption coefficient at $240 \mathrm{~nm}$ for $\mathrm{H}_{2} \mathrm{O}_{2}$ was taken to be $43.6 \mathrm{M}^{-1} \mathrm{~cm}^{-1}$ (Hildebrandt \& Roots, 1975). The reaction mixture contained $16 \mathrm{mM} \mathrm{H}_{2} \mathrm{O}_{2}$ and an appropriate amount of enzyme in $50 \mathrm{mM}$ potassium phosphate buffer $(\mathrm{pH} \mathrm{7 \cdot 0})$. The reaction was run at $30^{\circ} \mathrm{C}$ for $1 \mathrm{~min}$, and only the initial linear rate was taken to estimate activity. One unit of activity was defined as the disappearance of $1 \mu \mathrm{mol} \mathrm{H}_{2} \mathrm{O}_{2}$ $\min ^{-1}$.

Catalase activity staining. Native catalases were electrophoretically separated on $7 \%$ polyacrylamide gel according to Laemmli (1970). Staining for catalase activity was done by the method of Clare et al. (1984): the gel was soaked for $45 \mathrm{~min}$ in $50 \mathrm{mM}$ potassium phosphate buffer $(\mathrm{pH} 7 \cdot 0$ ) containing $50 \mu \mathrm{g}$ horseradish peroxidase $\mathrm{ml}^{-1}$, followed by addition of $5 \mathrm{mM}$ $\mathrm{H}_{2} \mathrm{O}_{2}$ for $10 \mathrm{~min}$. The gel was washed twice with distilled water, and then was soaked in $50 \mathrm{mM}$ potassium phosphate buffer ( $\mathrm{pH} 7.0$ ) containing $0.5 \mathrm{mg}$ diaminobenzidine $\mathrm{ml}^{-1}$ to develop the background brown colour. No colour would appear in the area where catalase depleted $\mathrm{H}_{2} \mathrm{O}_{2}$.

Purification of the major catalase from S. coelicolor. All the purification steps were carried out at $4{ }^{\circ} \mathrm{C}$ or on ice. Mycelium cultured for $48 \mathrm{~h}$ was harvested and washed twice with $10 \mathrm{mM}$ potassium phosphate buffer ( $\mathrm{pH} \mathrm{6.2).} \mathrm{The} \mathrm{washed} \mathrm{mycelium}$ was suspended in $50 \mathrm{mM}$ potassium phosphate buffer ( $\mathrm{pH} \mathrm{6.2)}$ and disrupted by abrasion with glass beads in a bead beater (Biospec). Cell debris was removed and the lysate was precipitated by adding ammonium sulfate to $70 \%$ saturation. The precipitates were dissolved in $50 \mathrm{mM}$ potassium phosphate buffer ( $\mathrm{pH} \mathrm{6.2)} \mathrm{and} \mathrm{applied} \mathrm{to} \mathrm{a} \mathrm{column} \mathrm{of} \mathrm{Sepharose} \mathrm{CL-4B}$ equilibrated with $50 \mathrm{mM}$ potassium phosphate buffer $(\mathrm{pH} \mathrm{6.2)}$ ). The fractions showing catalase activity were pooled and immediately applied, without further concentration or dialysis, to a column of DEAE-Sepharose CL-6B equilibrated with
$50 \mathrm{mM}$ potassium phosphate buffer ( $\mathrm{pH} \mathrm{6.2).} \mathrm{The} \mathrm{column} \mathrm{was}$ washed with $50 \mathrm{mM}$ potassium phosphate buffer $(\mathrm{pH} \mathrm{6.2)} \mathrm{and}$ then eluted with a linear gradient of $\mathrm{NaCl}(0-0.6 \mathrm{M})$. The fractions containing catalase activity were pooled and ammonium sulfate was added to a final concentration of $1 \mathrm{M}$. This was then applied to a Phenyl-Sepharose CL-4B column equilibrated with $0.5 \mathrm{M}$ ammonium sulfate in $10 \mathrm{mM}$ potassium phosphate buffer (pH 6.8). The column was washed with equilibration buffer and eluted with a descending gradient of $0 \cdot 5-0 \mathrm{M}$ ammonium sulfate. The eluate containing catalase was concentrated by ultrafiltration and stored at $4{ }^{\circ} \mathrm{C}$ for the subsequent analyses.

Molecular mass determination. The molecular mass of the native enzyme was determined by size exclusion on a Superose 6 column equilibrated with $0.25 \mathrm{M} \mathrm{NaCl}$ in $10 \mathrm{mM}$ potassium phosphate buffer ( $\mathrm{pH} 6 \cdot 8$ ). For molecular mass standards, the following proteins were used; ferritin $(440 \mathrm{kDa})$, aldolase $(158 \mathrm{kDa})$, bovine serum albumin $(66.2 \mathrm{kDa})$ and ovalbumin $(45 \mathrm{kDa})$. Subunit molecular mass was determined by SDSPAGE on a $10 \%(\mathrm{w} / \mathrm{v})$ acrylamide gel according to the procedure of Laemmli (1970).

Spectrophotometry. Absorption spectra were measured on Hewlett Packard Diode Array Spectrophotometer. The type and content of prosthetic haem group was determined as the pyridine haemochromogen by the method of Falk (1964) using pyridine-dithionite as a blank.

\section{Changes in catalase band patterns at different growth phases}

Different catalase activities present in crude extracts of $S$. coelicolor cells grown for various lengths of time in liquid minimal media were separated by electrophoresis on native polyacrylamide gel and visualized by activity staining (Fig. 1). Two catalase bands (Cat2 and Cat 4 ) were present in extracts of mycelia from the mid-exponential growth phase. As growth progressed changes in the catalase band pattern were observed. Mycelia from the late-exponential phase produced four catalase bands (Cat3, Cat4, Cat5 and Cat6), whereas mycelia from the stationary phase produced a Cat1 band, detectable only in this growth phase, in addition to those present in lateexponential phase. The synthesis of Cat 1 can be correlated with secondary metabolism. In $S$. coelicolor, secondary metabolism takes place only after rapid cell growth has ceased, and involves the biosynthesis of pigmented antibiotics. Cat1 was detectable only after cells began to produce pigments. Cat1 was also detected in purified spores along with the other catalases, except Cat2 (data not shown).

Growth-dependent expression of multiple catalases has previously been reported in E. coli (Loewen et al., 1985b) and B. subtilis (Loewen \& Switala, 1987a). In E. coli two types of catalase (HPI and HPII) were found to be produced. HPI is the major vegetative catalase and was shown to be induced when cells were treated with a sublethal level of $\mathrm{H}_{2} \mathrm{O}_{2}$. The expression of HPI is under the control of the oxy $\mathrm{R}$ gene product (Christman et al., 1985). HPII synthesis is elevated in the stationary phase as well as during growth on TCA cycle intermediates, and 


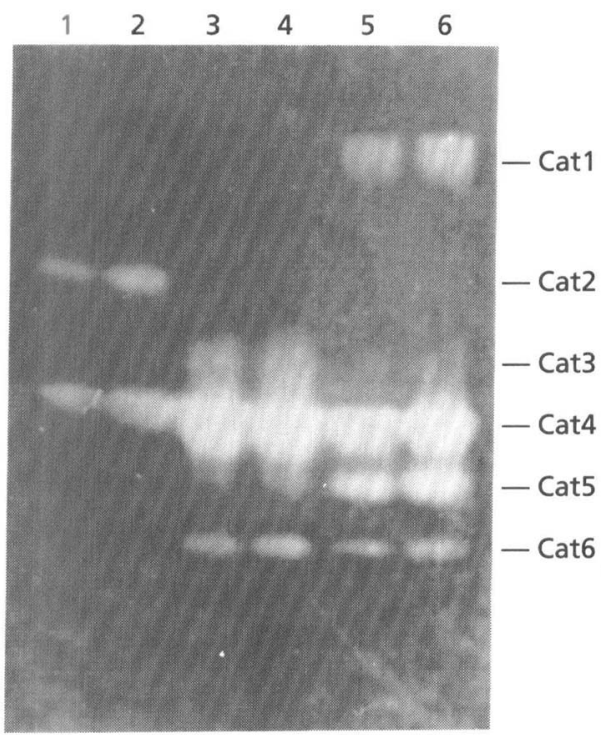

Fig. 1. Expression of multiple catalases with different electrophoretic mobilities in $S$. coelicolor at different growth phases. Cell extracts were obtained from cells grown for $30 \mathrm{~h}$ (mid-exponential growth phase; lanes 1 and 2), $48 \mathrm{~h}$ (lateexponential phase; lanes 3 and 4), or $10 \mathrm{~d}$ (stationary phase; lanes 5 and 6) after inoculation of germinated spores in minimal medium. Cells were either untreated (lanes 1, 3 and 5) or treated with $100 \mu \mathrm{M} \mathrm{H} \mathrm{O}_{2}$ for 30 min (lanes 2, 4 and 6) before harvest. Cell extracts containing $50 \mu \mathrm{g}$ protein were loaded on $7 \%$ native polyacrylamide gel. Catalase bands were stained negatively, as described in Methods.

regulated by the stationary-phase-specific regulator RpoS $(k a t F)$ (Loewen \& Triggs, 1984). B. subtilis produces two main species of catalase; catalase- 1 and catalase- 2 . Catalase- 1 is produced in vegetative cells and catalase- 2 is produced after cells have entered the stationary phase. Catalase-2 is the exclusive catalytic activity in purified spores. In S. coelicolor, Cat4 turned out to be the vegetative catalase present throughout all the growth phases, whereas Cat1 was the stationary-phase-specific enzyme. Except in mid-exponential phase, Cat3, Cat5 and Cat6 bands appeared at all growth phases in varying amounts. Cat 3 was more abundant in the exponential phase, whereas Cat5 was more abundant in the stationary phase. The presence of Cat 2 was transient and was observed only within a short period of time during the early phase of rapid growth. It is not certain whether each catalase activity band is a discrete enzyme or a variant in terms of charge or oligomerization status, since there have been reports that catalase- 2 of $B$. subtilis and catalase-peroxidase of Rhodopseudomonas capsulata appear as multiple bands, probably due to limited proteolysis (Loewen \& Switala, 1987a; Hochman \& Shemesh, 1987). In S. coelicolor, however, Cat 5 and Cat 6 are not the proteolytic products of Cat 4 , as indicated by Western blotting. Polyclonal antibody raised against purified Cat 4 reacted with a single polypeptide band on a blot of cell extracts electrophoresed on SDS-PAGE (data not shown). Whatever the nature of each enzyme band is, $S$. coelicolor Cat 4 corresponds to HPI of E. coli and catalase-1 of B. subtilis, whereas Cat1

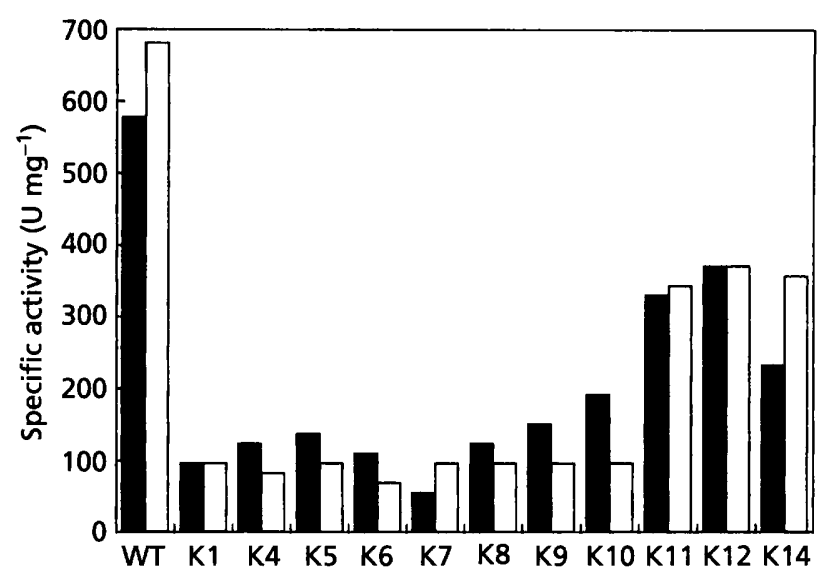

Fig. 2. Catalase activity in cell extracts from various catalasedeficient mutants. Non-bubbling and slow-bubbling mutants were selected as described in Methods and grown to either exponential ( $\square$ ) or stationary $(\square)$ phases. K1-K10, nonbubbling mutants; K11-K14, slow-bubbling mutants; WT, wildtype.

corresponds to HPII of E. coli and catalase-2 of B. subtilis, in terms of growth-phase-specific expression. To examine the inducibility of each catalase activity band in response to $\mathrm{H}_{2} \mathrm{O}_{2}$, mycelia at each growth phase were treated with $100 \mu \mathrm{M} \mathrm{H}_{2} \mathrm{O}_{2}$ for $30 \mathrm{~min}$ (Fig. 1, lanes 2, 4 and 6). Cat2 and Cat 4 activity bands increased slightly at the midexponential phase. However, since quantification by activity staining in the gel was insufficiently accurate, the extent of induction was not estimated.

\section{Isolation and characterization of mutants deficient in catalase activity}

To carry out a genetic investigation on the presence of multiple catalase genes in $S$. coelicolor, mutants deficient in catalase activity were isolated. From approximately 5000 surviving colonies, eight failed to evolve oxygen bubbles (non-bubbling mutant) and three evolved bubbles more slowly than the wild-type (slow-bubbling mutants). The catalase activity of these mutants was measured in extracts from cells at exponential and stationary growth phases (Fig. 2). All the mutants contained lower levels of catalase activity compared with the wild-type cells. Catalase activities in non-bubbling mutants were 10-30\% those of the wild-type at exponential growth phase and $10-15 \%$ at stationary growth phase. In slow-bubbling mutants, catalase activities were $40-60 \%$ those of the wild-type at exponential growth phase and about $50 \%$ at stationary growth phase. To determine the changes in the pattern of catalase activity bands for these mutants, activity staining of crude extracts was done. Table 1 summarizes the result of gel activity staining of extracts from mutants. In all the non-bubbling mutants, the Cat 4 band was significantly weakened or absent at both growth phases. In slowbubbling mutants, however, the Cat 4 band was observed at a similar level as that of the wild-type. In contrast, other catalase bands were weakened. Cat1, which was detected 
Table 1. Changes in catalase band patterns of catalase-deficient mutants

Band intensity: +++ , wild-type level; ++ , medium; + , weak; - , no activity.

\begin{tabular}{|c|c|c|c|c|c|c|c|c|c|c|c|c|}
\hline \multirow[t]{2}{*}{ Band } & \multirow{2}{*}{$\begin{array}{l}\text { Growth } \\
\text { phase* }\end{array}$} & \multicolumn{8}{|c|}{ Non-bubbling } & \multicolumn{3}{|c|}{ Slow-bubbling } \\
\hline & & K1 & K6 & $\mathbf{K} 7$ & K9 & K10 & K4 & K5 & K8 & K11 & K12 & K14 \\
\hline Cat1 & S & + & ++ & + & + & + & - & - & - & + & + & + \\
\hline \multirow[t]{2}{*}{ Cat3 } & $\mathrm{E}$ & ++ & + & ++ & ++ & +++ & - & - & - & - & +++ & - \\
\hline & $S$ & + & + & + & + & + & - & - & - & $++t$ & +++ & +++ \\
\hline \multirow[t]{2}{*}{ Cat4 } & $\mathrm{E}$ & - & - & - & - & - & + & + & + & +++ & +++ & +++ \\
\hline & $\mathrm{S}$ & - & + & + & + & - & + & + & + & +++ & +++ & +++ \\
\hline \multirow[t]{2}{*}{ Cat5 } & $\mathrm{E}$ & + & - & + & ++ & - & $++t$ & +++ & - & - & ++ & - \\
\hline & $\mathrm{S}$ & + & ++ & ++ & ++ & + & + & + & + & - & - & +++ \\
\hline Cat6 & $\begin{array}{l}E \\
S\end{array}$ & $\begin{array}{c}++ \\
+\end{array}$ & $\begin{array}{c}+ \\
++\end{array}$ & $\begin{array}{l}++ \\
++\end{array}$ & $\begin{array}{c}+++ \\
+\end{array}$ & $\begin{array}{c}+ \\
++\end{array}$ & $\begin{array}{c}++ \\
+\end{array}$ & $\begin{array}{c}+++ \\
++\end{array}$ & $\begin{array}{c}++ \\
+\end{array}$ & $\begin{array}{l}+ \\
+\end{array}$ & $\begin{array}{c}+++ \\
++\end{array}$ & $\begin{array}{c}+++ \\
++\end{array}$ \\
\hline
\end{tabular}

* E, Exponential phase, cultured for $48 \mathrm{~h}$ in minimal medium inoculated with germinated spores; $\mathrm{S}$, stationary phase, cultured for $10 \mathrm{~d}$ in minimal medium inoculated with germinated spores.

Table 2. Purification of the major catalase from S. coelicolor

\begin{tabular}{|lccccc|}
\hline Purification step & $\begin{array}{c}\text { Vol. } \\
\text { (ml) }\end{array}$ & $\begin{array}{c}\text { Total } \\
\text { protein } \\
\text { (mg) }\end{array}$ & $\begin{array}{c}\text { Total } \\
\text { activity } \\
\text { (units) }\end{array}$ & $\begin{array}{c}\text { Specific } \\
\text { activity } \\
\text { (units mg } \mathbf{~}^{-1} \text { ) }\end{array}$ & $\begin{array}{c}\text { Recovery } \\
\text { (\%) }\end{array}$ \\
\hline Crude extract & 70 & 359 & $2 \cdot 12 \times 10^{5}$ & 591 & 100 \\
Ammonium sulfate & 10 & 256 & $1 \cdot 90 \times 10^{\mathbf{5}}$ & 742 & 90 \\
Sepharose CL-4B & 118 & 63 & $1 \cdot 75 \times 10^{\mathbf{5}}$ & 2780 & 83 \\
DEAE Sepharose CL-6B & 49 & $8 \cdot 9$ & $5 \cdot 14 \times 10^{4}$ & 5780 & 24 \\
Phenyl Sepharose CL-4B & 8 & $0 \cdot 32$ & $4 \cdot 43 \times 10^{\mathbf{4}}$ & 138000 & 21 \\
\hline
\end{tabular}

only during the stationary growth phase, was weakened in all the catalase-deficient mutants. In this analysis, we were not able to correlate any two catalase bands which were reduced simultaneously in all the non-bubbling or slowbubbling mutants. Instead, different combinations of catalase bands were reduced in each mutant. It is highly unlikely that the enzymes in all the bands are encoded by a single gene since all the non-bubbling mutants contained at least $10 \%$ of catalase activity compared with the wildtype. From a separate study in our laboratory, we found at least two genes which contain homologous sequences with typical eukaryotic catalase (Y.H.Cho, personal communication). The reason for the simultaneous decrease in several catalase bands is not clear at this moment. Considering the mutation frequency, it is not plausible to assume multiple mutations in each mutant. If the expression of different catalases is correlated with growth phases, which are governed by many metabolic factors in cells, mutation in one catalase gene could change the intracellular environment and affect the expression of other genes in a complex regulatory circuit. On the other hand, if several catalase bands are variants in charge and/or oligomerization status, more than one band can be affected by a single mutation. To clarify this, further genetic study of genes encoding catalase is necessary. Whatever the situation is, the current results clearly indicate that there should be at least two catalase genes in $S$. coelicolor and Cat4, the catalase present in all growth phases, is the major catalase since all the non-bubbling mutants were deficient in its activity.

\section{Purification of the major catalase}

The typical purification steps for catalase from crude extracts are summarized in Table 2. This procedure resulted in about 230 -fold purification with $21 \%$ yield. Catalase activity was detected as a single broad peak in Sepharose CL-4B eluate fractions, containing Cat3, 4, 5 and 6 activities. When these fractions were run on a DEAE Sepharose CL-6B column, only Cat4 activity was detected in fractions eluted by $0.2-0.3 \mathrm{M} \mathrm{NaCl}$. The purified enzyme preparation showed a single protein band near homogeneity on both native (Fig. 3a) and SDSpolyacrylamide gel (Fig. 3b). Activity staining of the native gel revealed that this protein corresponded to Cat 4 (Fig. 3a, lane 2). SDS-PAGE with several molecular mass markers revealed that the enzyme is composed of a single type of subunit with a molecular mass of $57 \mathrm{kDa}$. This 
(a)

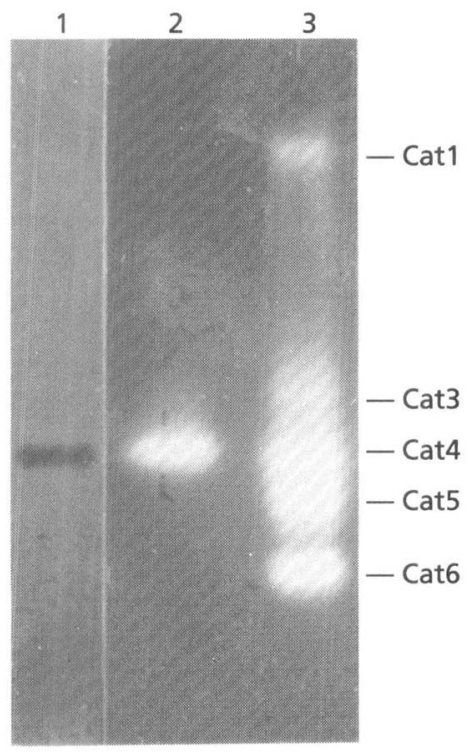

(b)

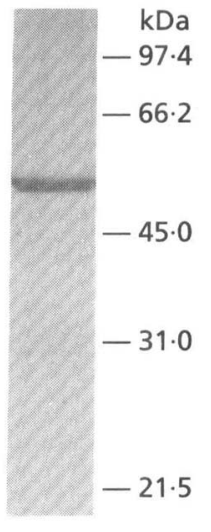

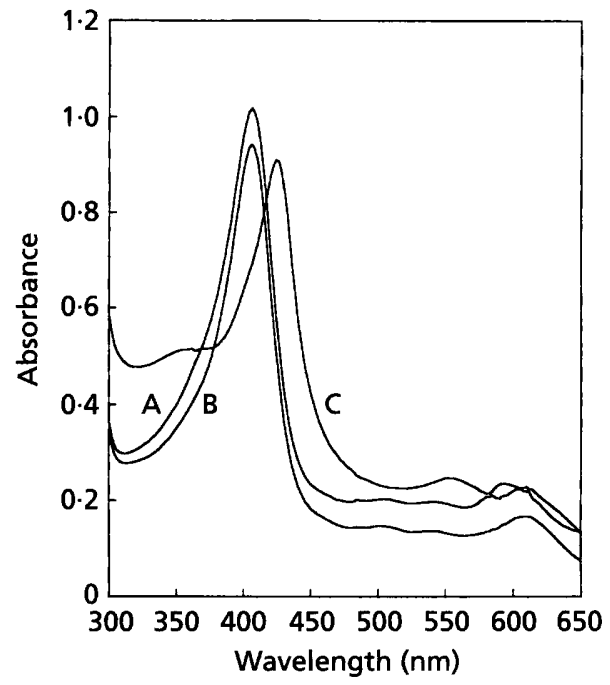

Fig. 4. Absorption spectra of purified Cat4. The spectra of enzyme in $10 \mathrm{mM}$ potassium phosphate buffer ( $\mathrm{pH} 6.8)$ were recorded against a blank containing buffer only. $A$, native enzyme; B, enzyme treated with $1 \mathrm{mM}$ sodium dithionite; $C$,

3. (a) Electrophoretogram of purified Cat4 on $7 \%$ denaturing polyacrylamide gel. Lanes: 1 , purified Cat4 stained with Coomassie brilliant blue $G ; 2$, purified Cat4 stained for catalase activity; 3 , crude extracts of cells at stationary phase stained for catalase activity. (b) Electrophoretogram of purified Cat4 on SDS-polyacrylamide gel. The gel was stained with Coomassie brilliant blue $\mathrm{G}$. The position of molecular mass markers is indicated on the right.

enzyme was found to contain no significant peroxidase activity when assayed using o-dianisidine and diaminobenzidine as substrates. The purified Cat 4 was electrophoresed on polyacrylamide gel with $\mathrm{pH}$ gradient of $3-10$, and the isoelectric point was determined to be $5 \cdot 1$.

\section{Molecular mass determination of the native enzyme}

The molecular mass of the purified native enzyme was determined by gel filtration through a Superose 6 column. Compared with several size markers, the molecular mass was estimated to be approximately $225 \mathrm{kDa}$. Considering the subunit molecular mass, this enzyme appears to be a tetramer composed of four identical subunits.

\section{Spectroscopic properties}

The absorption spectrum of the purified catalase exhibited a soret peak at $406 \mathrm{~nm}$ and an additional minor peak at $610 \mathrm{~nm}$ (Fig. 4, spectrum A). Treatment of the enzyme with sodium dithionite did not alter the spectral shape (Fig. 4, spectrum B), indicating that Cat4, like other typical monofunctional catalases from eukaryotic sources, is resistant to reduction. This characteristic is consistent with the above observation that Cat4 lacks peroxidase activity. Treatment of the enzyme with $\mathrm{KCN}$ shifted the maximum of the soret band to $424 \mathrm{~nm}$ and resulted in the appearance of minor peaks at $554 \mathrm{~nm}$ and $594 \mathrm{~nm}$ (Fig. 4, spectrum C). The efficient formation of a cyanide complex is further evidence for the presence of ferric haem in the

enzyme treated with $10 \mathrm{mM} \mathrm{KCN}$.

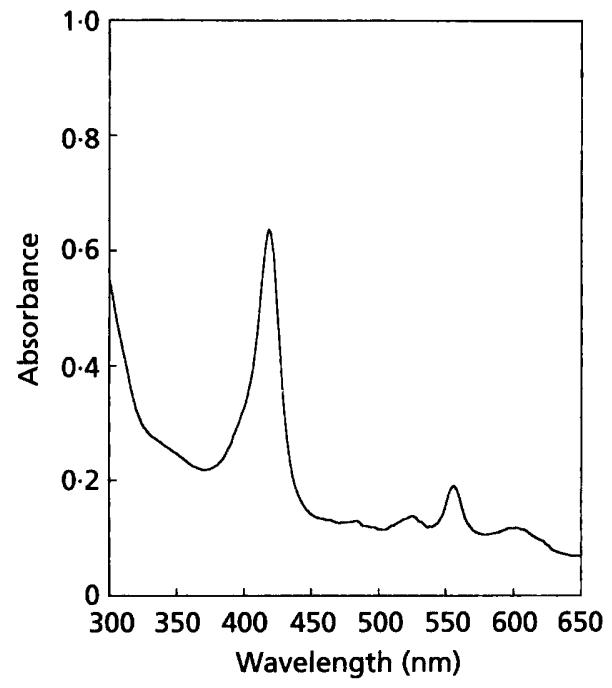

Fig. 5. Absorption spectrum of pyridine haemochrome of $S$. coelicolor Cat4. Enzyme $(1.27 \mu \mathrm{M})$ was incubated in $10 \mathrm{mM}$ potassium phosphate buffer $(\mathrm{pH} \mathrm{6.8)}$ containing $0.1 \mathrm{M} \mathrm{NaOH}$, $20 \%(\mathrm{w} / \mathrm{v})$ pyridine and $1 \mathrm{mM}$ sodium dithionite for $1 \mathrm{~min}$ before spectrophotometric measurement.

enzyme and indicates that the haem ligand of Cat4 might be tyrosine phenolate, as in other typical catalases (Reid $e t$ al., 1981; Fita \& Rossman, 1985). Treatment of the enzyme with pyridine $/ \mathrm{NaOH}$ and sodium dithionite produced pyridine haemochrome whose major absorption peaks appeared at 418, 526 and $556 \mathrm{~nm}$ (Fig. 5). This indicates that Cat 4 contains protohaem IX as its haem group. The protohaem content of this enzyme was determined from the absorption of its pyridine hae- 
mochromogen at $418.5 \mathrm{~nm}$, on the basis of the relationship, $\varepsilon_{418.5}=191.5 \times 103 \mathrm{M}^{-1} \mathrm{~cm}^{-1}$ (Falk, 1964). We estimated that there are 2.6 molecules of protohaem IX per tetrameric molecule of Cat 4 . The haem content as well as the $A_{405} / A_{280}$ ratio of 1.0 again indicates that Cat 4 shares many properties with the typical monofunctional catalases.

\section{Inhibitors}

The effect of $\mathrm{KCN}, \mathrm{NaN}_{3}$, hydroxylamine, $\beta$ mercaptoethanol and sodium dithionite on the enzyme activity was examined. Treatment for $1 \mathrm{~min}$ with $1 \mathrm{mM}$ $\mathrm{KCN}, 0.1 \mathrm{mM} \mathrm{NaN}_{3}$ and $0.5 \mathrm{mM}$ hydroxylamine inhibited enzyme activity by 95,97 and $63 \%$, respectively. $\beta$-Mercaptoethanol and sodium dithionite were moderate inhibitors at $1 \mathrm{mM}$, inhibiting catalase activity by 36 and $13 \%$, respectively.

\section{Protein stability}

Cat 4 retained $100 \%$ of its activity when treated with a mixture of ethanol/chloroform (enzyme solution: $95 \%$ ethanol:chloroform $=10: 5: 3$, by vol.) for $10 \mathrm{~min}$ with vortexing at room temperature. When the purified enzyme was incubated at various temperatures for $5 \mathrm{~min}$, full activity remained at temperatures up to $40^{\circ} \mathrm{C}$. At $50^{\circ} \mathrm{C}$, however, about $60 \%$ of the activity measured at $30^{\circ} \mathrm{C}$ remained, and at $60^{\circ} \mathrm{C}$ the enzyme was completely inactivated. Incubation of Cat 4 for $2 \mathrm{~min}$ in the presence of $8 \mathrm{M}$ urea also caused its complete inactivation. The effect of $\mathrm{pH}$ on Cat 4 activity was also determined. Catalase activity showed a broad maximum in the range of pH 5.5-9.5.

The major vegetative catalase Cat 4 isolated from $S$. coelicolor shares general molecular properties with typical eukaryotic catalases. Bacterial catalases that closely resemble the typical eukaryotic catalase, with four protohaem IX groups associated with a tetramer of subunits of approximately $60 \mathrm{kDa}$, have been shown to be produced in Micrococcus lysodeikticus (Herbert \& Pinsent, 1948) and Proteus mirabilis (Jouve et al., 1983). Other than these, Cat 4 differs in its molecular properties from other bacterial monofunctional catalases. E. coli HPII (Loewen \& Switala, 1986) and B. subtilis catalase-2 (Loewen \& Switala, 1987c), both of which are expressed in the stationary phase, contain six haem $\mathrm{D}$-isomer prosthetic groups in a hexameric structure of larger subunits. E. coli HPI (Claiborne \& Fridovich, 1979) and catalase from R. capsulata (Hochman \& Shemesh, 1987), Halobacterium balobium (Brown-Peterson \& Salin, 1993) and facultative alkalophilic Bacillus species (Yumoto et al., 1990) are bifunctional catalase-peroxidases. The catalases of Comamonas compransoris (Nies \& Schlegel, 1982), Mycobacterium tuberculosis (Diaz \& Wayne, 1974) and Streptomyces venezuelae (Knoch et al., 1989) have a molecular mass of $150-160 \mathrm{kDa}$, and consist of two identical subunits.

We have shown in this paper that among six catalase activities with different electrophoretic mobilities and growth-specific expression patterns, Cat4 is the major catalase. We compared its molecular properties with other known catalases and found that the enzyme is distinctly different from the vegetative catalase from $E$. coli in both its enzymic characteristics and the makeup of the catalase active centre. The limited information on the vegetative catalase (catalase-1) of $B$. subtilis, suggests that $S$. coelicolor Cat4 has similar properties, except that $B$. subtilis catalase1 is a hexameric enzyme (Loewen \& Switala, 1987b).

\section{ACKNOWLEDGEMENTS}

This work was supported by a grant from the Korea Science and Engineering Foundation for SRC (Research Center for Molecular Microbiology) to J.-H. Roe and Y. C. Hah. The authors are thankful to Professor S.-O. Kang and H. D. Youn for providing useful advice on the purification of the enzyme.

\section{REFERENCES}

Baserga, R. (1989). Measuring parameters of growth. In Cell Growth and Division, pp. 1-16. Edited by R. Baserga. Oxford: IRL Press.

Beers, R. F., Jr \& Sizer, I. W. (1952). A spectrophotometric method for measuring the breakdown of hydrogen peroxide by catalase. $J$ Biol Chem 195, 276-287.

Brown-Peterson, N. J. \& Salin, M. L. (1993). Purification of a catalase-peroxidase from Halobacterium balobium: Characterization of some unique properties of the halophilic enzyme. J Bacteriol 175, 4197-4202.

Cadenas, E. (1989). Biochemistry of oxygen toxicity. Annu Rev Biochem 58, 79-110.

Christman, M. F., Morgan, R. W., Jacobson, F. S. \& Ames, B. M. (1985). Positive control of a regulon for defense against oxidative stress and some heat-shock proteins in Salmonella typhimurium. Cell 41, 753-762.

Claiborne, A. \& Fridovich, I. (1979). Purification of the 0 -dianisidine peroxidase from Escherichia coli B. J Biol Chem 254, 4245-4252.

Claiborne, A., Malinowski, D. P. \& Fridovich, I. (1979). Purification and characterization of hydroperoxidase II of Escherichia coli B. $J$ Biol Chem 254, 11664-11668.

Clare, D. A., Duong, M. H., Darr, D., Archibald, F. \& Fridovich, I. (1984). Effects of molecular oxygen on detection of superoxide radical with nitroblue tetrazolium and on activity stains for catalase. Anal Biochem 140, 532-537.

Clayton, R. K. (1959). Purified catalase from Rhodopseudomonas spheroides. Biochim Biophys Acta 36, 40-47.

Deisseroth, A. \& Dounce, A. L. (1970). Catalase: physical and chemical properties, mechanism of catalysis and physiological role. Pbysiol Rev 50, 319-375.

Diaz, G. A. \& Wayne, L. G. (1974). Isolation and characterization of catalase produced by Mycobacterium tuberculosis. Am Rev Resp Dis 110, 312-323.

Dunford, H. B. \& Stillman, J. S. (1976). On the function and mechanism of action of peroxidases. Coord Chem Rev 19, 187-251.

Esaka, M. \& Asahi, T. (1982). Purification and properties of catalase from sweet potato root microbodies. Plant Cell Pbysiol 23, 315-322.

Falk, J. E. (1964). Porpbyrines and Metalloporpbyrines. New York: Elsevier.

Fita, I. \& Rossman, M. G. (1985). The active center of catalase. J Mol Biol 185, 21-37.

Goldberg, I. \& Hochman, A. (1989a). Purification and charac- 
terization of a novel type of catalase from the bacterium Klebsiella pneumoniae. Biochim Biopbys Acta 991, 330-336.

Goldberg, I. \& Hochman, A. (1989b). Three different types of catalases in Klebsiella pneumoniae. Arch Biochem Biophys 268, 124-128.

Halliwell, B. (1990). How to characterize a biological antioxidant. Free Radicals Res Commun 9, 1-32.

Herbert, D. \& Pinsent, J. (1948). Crystalline bacterial catalase. Biocbem J 43, 193-202.

Hildebrandt, A. G. \& Roots, I. (1975). Reduced nicotinamide adenine dinucleotide phosphate (NADP)-dependent formation and breakdown of hydrogen peroxide during mixed function oxidation reactions in liver microsomes. Arch Biochem Biophys 171, 385-397.

Hochman, A. \& Shemesh, A. (1987). Purification and characterization of a catalase-peroxidase from the photosynthetic bacterium Rhodopseudomonas capsulata. J Biol Chem 262, 6871-6876.

Hochman, A., Figueredo, A. \& Wall, J. D. (1992). Physiological function of hydroperoxidases in Rhodobacter capsulatus. J Bacteriol 174, 3386-3391.

Hopwood, D. A., Bibb, M. J., Chater, K. F., Kieser, T., Bruton, C. J., Lydiate, D. J., Smith, C. P., Ward, J. M. \& Schrempf, H. (1985). Genetic Manipulation of Streptomyces. A Laboratory Manual. Norwich: John Innes Institute.

Jones, K. L. (1949). Fresh isolates of actinomycetes in which the presence of sporogenous aerial mycelia is a fluctuating characteristic. J Bacteriol 57, 141-145.

Jouve, H. M., Lasouniere, C. \& Pelmont, J. (1983). Properties of a catalase from a peroxide resistant mutant of Proteus mirabilis. Can J Biocbem Cell Biol 61, 1219-1227.

Knoch, M., Van Pée, K. H., Vining, C. \& Lingens, F. (1989). Purification, properties and immunological detection of a bromoperoxidase-catalase from Streptomyces venezuelae and from a chloramphenicol-nonproducing mutant. $J$ Gen Microbiol 135, 2493-2502.

Laemmli, U. K. (1970). Cleavage of structural proteins during the assembly of the head of bacteriophage T4. Nature 227, 680-685.

Lee, J. S., Hah, Y. C. \& Roe, J. H. (1993). The induction of oxidative enzymes in Streptomyces coelicolor upon hydrogen peroxide treatment. J Gen Microbiol 139, 1013-1018.

Lee, J. S. (1994). The response of Streptomyces coelicolor (Müller) against bydrogen peroxide stress. $\mathrm{PhD}$ thesis, Seoul National University, Korea.

Loewen, P. C. \& Switala, J. (1986). Purification and characterization of catalase HPII from Escherichia coli. Biocbem Cell Biol 64, 638-646.

Loewen, P. C. \& Switala, J. (1987a). Multiple catalases in Bacillus subtilis. J Bacteriol 169, 3601-3607.
Loewen, P. C. \& Switala, J. (1987b). Purification and characterization of catalase-1 from Bacillus subtilis. Biochem Cell Biol 65, 939-947.

Loewen, P. C. \& Switala, J. (1987c). Purification and characterization of spore specific catalase-2 from Bacillus subtilis. Biochem Cell Biol 66, 707-714.

Loewen, P. C. \& Triggs, B. L. (1984). Genetic mapping of kat $F$, a locus that with kat $E$ affects the synthesis of a second catalase species in Eschericbia coli. J Bacteriol 160, 668-675.

Loewen, P. C., Triggs, B. L., George, C. S. \& Hrabarchuk, B. E. (1985a). Genetic mapping of $\mathrm{katG}$, a locus that affects synthesis of the bifunctional catalase-peroxidase hydroperoxidase I in Eschericbia coli. J Bacteriol 162, 661-667.

Loewen, P. C., Switala, J. \& Triggs-Raine, B. L. (1985b). Catalases HPI and HPII in Escherichia coli are induced independently. Arch Biochem Biophys 243, 144-149.

Margoliash, E., Novogrodsky, A. \& Schejter, A. (1960). Irreversible reaction of 3-amino-1:2:4-triazol and related inhibitors with the protein of catalase. Biochem J 74, 339-348.

Morgan, R. W., Christman, M. F., Jacobson, F. S., Storz, G. \& Ames, B. N. (1986). Hydrogen peroxide-inducible proteins in Salmonella typhimurium overlap with heat shock and other stress proteins. Proc Natl Acad Sci US A 83, 8059-8063.

Nadler, V., Goldberg, I. \& Hochman, A. (1986). Comparative study of bacterial catalases. Biochim Biophys Acta 882, 234-241.

Nies, D. \& Schlegel, H. G. (1982). Catalase from Comamonas compransoris. J Gen Appl Microbiol 28, 311-319.

Reid, T. J., III, Murthy, M. R. N., Sicignano, A., Tanaka, N., Musick, D. W. L. \& Rossman, M. G. (1981). Structure and heme environment of beef liver catalase at $2.5 \AA$ resolution. Proc Natl Acad Sci US A 78, 4767-4771.

Schonbaum, G. R. \& Chance, B. (1976). Catalase. In The Enzymes, 2nd edn, vol. 13, pp. 363-408. Edited by P. D. Boyer. New York: Academic Press

Seah, T. C. M. \& Kaplan, J. G. (1973). Purification and properties of the catalase of baker's yeast. J Biol Chem 248, 2889-2893.

Seah, T. C. M., Bhatti, A. R. \& Kaplan, J. G. (1973). Novel catalytic proteins of baker's yeast. I. An atypical catalase. Can J Biochem 51, $1551-1555$

Yumoto, I., Fukumori, Y. \& Yamanaka, T. (1990). Purification and characterization of catalase from a facultative alkalophilic Bacillus. $J$ Biocbem 108, 583-587.

Received 10 June 1994; revised 28 July 1994; accepted 16 August 1994. 